cerning their history is contained in the following passage from Stephens:- "This species appears to be very rare in this country. I have hitherto seen, so far as I remember, two examples only, which are in my own collection, and were found in the vicinity of the Metropolis in the autumn, I believe at Hampstead" (Illus. Brit. Ent. Mandib. vi. p. 13, 1835).

In 1850, J. C. Dale presented to the British Museum, among other insects, a pair of Metrioptera from Parley Heath, Hants, which were believed to be "Acrida brevipennis," Charp. ( $=M$. roeselii, Hagenb.), and were referred to under that specific name in Walker's Cat. Derm. Salt. in B. M., part ii., p. 256 (1869). In the Museum collection, however, the specimens stand over the name brachyptera, Linn., and Dr. Burr has kindly informed me that they are correctly placed.

Assuming that Mr. Waterhouse's specimens were taken in July, it follows that the ascertained seasonal range of roeselii in this country extends from the latter part of that month to September 13th, the date noted by myself. Judging by analogy with allied species, however, our insect might be expected to survive until about October.

58, Ranelagh Road, Ealing: March 2nd, 1912.

\title{
SOME BEES OF THE GENUS NOMIA FROM AUSTRALIA.
}

\section{By T. D. A. Cockerell.}

Nomia flavoviridis, Cockerell.

I Have before me a series of eight males and seventeen females collected by Turner at Mackay, Queensland; some of the females from flowers of Cassia and Xanthorrhoea. I have also eight males from Cooktown, October, 1902 (Turner), four males from Townsville (Dodd), and a female collected at Cheltenham, Victoria, by French (Froggatt collection, 96). The abdominal bands vary in colour from pale yellowish to white in the males, and in the females are frequently orange. Both sexes are occasionally only rather feebly metallic. So far as can be gathered from Smith's brief account of male $N$. anea from Port Essington, the only conspicuous and constant difference between that species and $N$. flavoviridis is found in the hind femora, which in anea are more slender than in male flavoviridis, and have the apical part much more narrowed and elongated.

The great variability of $N$. flavoviridis makes the classification of the varieties difficult. None of the specimens now before me are var. adelaidella, Ckll. The typical flavoviridis is represented only by two males and a female from Mackay, characterised by 
the clear rufo-fulvous or apricot colour of the tegulæ, and in the male by the red tibiæ (wholly red or stained with metallic greenish) and tarsi. The female has pale orange hair-bands. The other specimens all have darker tegulæ, and the legs show more dark colour, being better described as dark stained with reddish. The colour of the body seems quite inconstant, the Mackay males varying from green to deep blue. It therefore seems impracticable to maintain the variety doddii, Ckll., unless it is considered to include all of the Queensland material excepting the three typical flavoviridis cited above. The female from Victoria is olive green, and has the face narrower than usual. Three females from North-west Australia (French) have very broad faces; they perhaps represent a distinct race.

\section{Nomia frenchi, sp. $\mathrm{n}$.}

๙. Length about $7 \frac{1}{2} \mathrm{~mm}$., expanse nearly 18 ; black, densely punctured, with dull white and black hair; antennæ very long, entirely black; clypeus black, somewhat bigibbous, shining, with elongate punctures; labrum and mandibles ferruginous, the latter black at tip; tongue narrow, moderately long; hair of face white, strongly plumose, of vertex fuscous, of occiput white; mesothorax uniformly densely punctured, with a thin short mouse-coloured tomentum, and longer black or dark fuscous hair; scutellum with long dark hair; other parts of thorax with pale hair; basal transverse canal of metathorax quite broad, shining, very finely fluted; apical triangular part of enclosure smooth and shining; tegulæ rather large, bright ferruginous, pointed behind; wings dusky translucent, nervures and stigma ferruginous; first r. n. entering apical corner of the narrow second s. m.; femora black, tibiæ and tarsi ferruginous, the middle and anterior tibiæ suffused with dusky; hind femora thickened, smooth, flattened and longitudinally concave beneath; hind tibiæ thickened, trigonal, the lower margin obtusely angled about the middle; abdomen black, densely punctured, the hind margins of the second and following segments smooth, the fourth and fifth becoming brownish; fourth ventral segment emarginate; no ventral tubercles or teeth.

$H a b$. Woodend, Victoria, 1909 (French). Froggatt collection, 92. A distinct species, readily separated from $N$. generosa, Smith, by the enlarged hind femora and tibiæ, and the dark hair on the thorax above; and from N. argentifrons, Smith, by the black flagellum, the red tibiæ and tarsi, \&c. The abdomen has greyish-white hair-bands on the second and following segments, that on the second broadly interrupted, but the basal parts of the third and following segments have long coarse black or dark fuscous hair.

\section{Nomia satelles, sp. n.}

ð. Length about $8 \frac{1}{2} \mathrm{~mm}$.; black, finely and closely punctured; hair on face dense, shining, with a yellowish-grey tint, on thorax above of the same colour, with scattered dark hairs intermixed, on 
pleura and sides of metathorax thin and white; tongue elongate daggershaped; lower half of clypeus, and mandibles except at base, honeycolour ; vertex and cheeks very narrow ; antennæ long, the flagellum entirely ferruginous, but darker above; mesothorax shining between the close small punctures; basal transverse channel of metathorax shining, crossed by numerous strong ridges; apical triangle of enclosure small, smooth ; tegulæ rather large, apricot colour, the margin paler; wings hyaline, faintly dusky; nervures and stigma ferruginous, first r. n. joining apical corner of second s. m. ; legs with coarse white hair; knees and tarsi clear ferruginous, tibiæ ferruginous at each end, as also anterior pair in front, and hind ones largely behind; hind femora swollen, shining; hind tibiæ swollen, trigonal, but wholly without the median tooth or tubercle found in N. smithella, Gribodo; abdomen finely but very distinctly punctured, with very broad pale orange hair-bands on the hind margins of the segments except the first, which has only an elongate patch on each side; venter without teeth or tubercles, hind margin of fourth ventral segment concave.

q. Length about $9 \frac{1}{2}$ or $10 \mathrm{~mm}$. ; similar to the male except for the usual sexual differences; hair on last two abdominal segments pale purplish-sooty, but the orange bands on the other segments as in the male; mesothorax with very minute punctures, and scattered large ones; mandibles dark; flagellum dark above, clear furruginous beneath; hair on inner side of basitarsi fulvous.

$H a b$. Type (male) from Rutherglen, Victoria, 1909 (French); Froggatt collection, 84. Female from Mittagong, New South Wales, January 10th, 1902 (Froggatt, 73). This species resembles $N$. australica, Smith, from which it is easily known by the smaller size and black colour. The first abdominal segment of the female is closely and finely punctured on the disc as in typical australica from New South Wales.

\section{Nomia kurandina, Ckll.}

I have a male from Kuranda, Cairns, March, 1902 (Turner), and two females from Mackay, Queensland, November, 1891, and May, 1900 (Turner, 1078). The female, not before known, is exactly like the male except for the usual sexual differences, and the more dilute dark apices of the wings. The clypeus and supraclypeal area show a strong median ridge. The mesothorax has very fine punctures, with scattered larger ones.

\section{Nomia semiaurea, Ckll.}

Mr. Turner collected females in Queensland, at Mackay, March, 1900, and at Cairns (Kuranda), April, 1902. At Kuranda, February, 1902, he collected a male N. rufocognita, Ckll. When describing N. semiaurea I suggested that it might possibly be the female of rufocognita, and I am now of the opinion that this is really the case, though actual proof is wanting. 


\section{Nomia halictella, Ckll.}

The male, hitherto undescribed, was taken at Mackay, January and March, 1900 (Turner, 314). It has a subclavate abdomen, and resembles N. pseudoceratina, Ckll., but is smaller (length about or hardly $8 \mathrm{~mm}$.), with the first abdominal segment only about as long as broad; hind knees and base of their tibiæ ferruginous; hind femora and tibiæ quite simple.

University of Colorado, Boulder :

January 18th, 1912.

\section{NOTES ON THE LIFE-HISTORY OF COLIAS NASTES VAR. WERDANDI, WITH DESCRIPTION OF OVA AND LARVA.}

By W. G. Sheldon, F.E.S.

Whilst staying in Swedish Lapland last summer I searched for and succeeded in finding ova of this species. The first ova, ten in number, were found on June 23rd in a sheltered spot on the shores of the Torne Träske, where its food-plant, the handsome Astragalus alpinus, grew abundantly. Most of the ova were found on the leaflets of the Astragalus, some on the upper and some on the lower surfaces, but in two cases they were attached to a leaf of Vaccinium myrtillus, which was an inch or two away from the food-plant. I did not search further for ova for some days, the supply obtained appearing sufficient for the time being, but in early July I sleeved several females, which deposited sparingly on the food-plant. I commenced to search again on July 10 th, but by this date the bulk of the larvæ had apparently emerged, for several hours' search only revealed five ova, all of which hatched during the next day or two.

The ova is of a pale straw-colour when deposited, gradually changing to deep orange in a few days, and shortly prior to emergence to dark leaden tint. It is upright, and of the usual Colias shape and character. The vertical and horizontal diameters are 1.25 millim. and 65 millim. respectively; it has a number of vertical ribs, the distance these are apart is about -05 millim.; numerous transverse ribs connect the vertical ones. The diameter of the apex of the ova is 15 millim. The micropylar area consists of a number of very shallow cells; it is not perceptibly depressed. The surface of the ova is highly glazed; that portion which from the position in which it is held reflects the light is tinged with mother-of-pearl.

This stage appears to last about twelve days, for one ova I had continuously under observation was, when found on June 


\section{$2 \mathrm{BHL}$ Biodiversity Heritage Library}

Cockerell, Theodore D. A. 1912. "Some bees of the genus Nomia from Australia." The Entomologist 45, 119-122.

https://doi.org/10.5962/bhl.part.9918.

View This Item Online: $\underline{\text { https://www.biodiversitylibrary.org/item/38260 }}$

DOI: https://doi.org/10.5962/bhl.part.9918

Permalink: https://www.biodiversitylibrary.org/partpdf/9918

\section{Holding Institution}

Smithsonian Libraries

\section{Sponsored by}

Smithsonian

\section{Copyright \& Reuse}

Copyright Status: NOT_IN_COPYRIGHT

This document was created from content at the Biodiversity Heritage Library, the world's largest open access digital library for biodiversity literature and archives. Visit BHL at https://www.biodiversitylibrary.org. 